\title{
Identification of variety management variables for product development and establishment of maturity levels
}

\author{
Régis Kovacs Scalice ${ }^{a}$, Jaqueline Nazario Ostetto ${ }^{b}$ José Oliveira da Silva ${ }^{b}$, Silene Seibel \\ Universidade Federal de Santa Catarina - UFSC \\ bUniversidade do Estado de Santa Catarina - UDESC \\ e-mails: regis.scalice@ufsc.br; jaqueostetto@hotmail.com; jose.silva@udesc.br; silene@silene.com.br
}

\begin{abstract}
The importance of expanding a company's variety of products is easily observed in competitive markets, where a greater variety means a greater chance of meeting specific consumer needs. On the other hand, a larger product list implies the need for better variety management. In this article, we study how two companies deal with variety management during product development, in order to identify the factors and variables linked to their success. Three axes are observed to be central to effective variety management: variety, flexibility and integration. Furthermore, technical variables were also identified that enable a company to manipulate such axes. For each variable, levels of maturity are established that enabled the identification of how those companies perform their variety management. As result, a tool is delivered that can evaluate an organization's maturity level regarding variety management. The proposed tool is also capable of performing competitive benchmarks between different organizations.
\end{abstract}

Keywords: variety management, product development process, maturity level.

\section{Introduction}

There is an old motto that states that "the customer is always right". Regardless of its simplicity, it clearly illustrates the evolution of the industrial model, for example, from the high standardized Fordism ("any customer can have a car painted any color that he wants so long as it is black") to a more recent mass customization model.

This trend for a high level of customization forces industrial companies to deal with a highly varied product portfolio. If we add the competitive need to continuously deliver new products to this context, the result is an increasing level of complexity to the manufacture and the supply chain.

Product variety can be defined as the number of different product versions offered by an enterprise in a specific time period (RANDALL; ULRICH, 2001). For the authors, increasing product variety may draw more customers, however, it implies greater barriers and difficulties to correctly manage such higher variety concurrently to aimed profits and objectives. ElMaraghy et al. (2009) emphasize that variety is not related only to the introduction of new product or process lines, but also to changes on existing products.

On the product side, variety has been a long-time concern. Authors such as (COOPER, 2001) and (CLARK; WHEELRIGHT, 1993) emphasized the need for enterprises to improve their Product Development Processes (PDP), aiming at the capacity to prioritize more relevant projects, in value or strategy. They aim at balancing their different short and long-term objectives according to the enterprise's strategy and directly impact on the management of product variety formation.

A good new product variety management provides better results on the ongoing enterprise processes, since its absence yields a discontinuous and disorderly flow of information to the manufacture. For Jião et al. (2007) and Tseng, Chang and Li (2008), such poor information flow is due to the higher variety, leading to an increased complexity on the manufacturing processes and impairing them, due to the greater number of products.

However, as previously stated, companies have been dealing with increasing variety levels for the last century. This, in turn, raises two questions for investigation: first, how those companies deal with variety in the different steps from product development, manufacture, and final delivery; and second, if it is possible to combine such variety management practices into a maturity level tool to aid other companies to achieve better variety management skills. Based on the two questions above, our objectives can be stated as: 
- Find the main axes that regulate the variety management during product development phases;

- Unfold such axes into variables that can be used to define variety management maturity levels.

To address such questions, we performed an initial study on two different companies to better understand how they manage their product variety during the Product Development Process (PDP), resulting in the parameters for our proposal. Next, we performed a bibliographical study to better understand the parameters' behavior. Based on those pieces of information, we proposed maturity levels for each parameter and established a procedure to support their use. We evaluated the proposed tool by applying it to three different companies.

\section{Literature review}

We previously described that variety is created by an enterprise's Product Development Process (PDP). During that process, several actions are taken to plan and control such creation, to adequate it to the enterprise's production capacity. The literature review focuses on those observations, derived from the three variables - variety, flexibility and integration, and their interaction with elements extracted from the variety management cases previously described. It includes: portfolio management, modularity and standardization, and concurrent engineering.

\subsection{Porffolio management}

According to Cooper et al. (1998), portfolio management is a dynamic decision process where a list of products is continuously revised. It is the manifestation of the business strategy and it will determine the future investments. So, in our understanding, it is how the company regulates the creation of variety.

There are three main objectives in portfolio management (COOPER; EDGETT; KLEINSCHIMIDT, 1998): to maximize portfolio value; to produce a balanced portfolio and to align the portfolio and the company's strategy. Those objectives may be employed separately or in different combinations, depending on the company's objectives. Other authors (JONAS; KOCK; GEMUENDEN, 2013; MESKENDAHL, 2010) also include two other, more specific, objectives for portfolio management: average of well-succeeded projects (schedule, costs, quality, etc.) and exploration of synergies in the portfolio projects.

Several authors have studied the elements that provide a good portfolio selection. They include criteria fairness when comparing different projects (ARCHER; GHASEMZADEH, 1999), information quality (JONAS; KOCK; GEMUENDEN, 2013), and the need to evaluate marketing and technology tendencies, and resource limitations (HALL; NAUDA, 1990). Oh et al. (2012) claim that present consumer market is becoming more versatile and technology changes are faster than ever. For the authors, the PDP success relies on the ability to predict market demands and to select project proposals that are more viable to meet such demands.

The importance of technology and market evaluation can easily be observed on the work of Oliveira and Rozenfeld (2010). The authors presented a reference model which integrates Technology Roadmapping (TRM) techniques within portfolio management. In that model, the product strategy definition occurs based on an individual business strategy, product, market and technology analysis, followed by the portfolio management usual practices.

Form that overview, five central elements can be extracted that allow the portfolio management to control product variety. They are a good selection, followed by the management of projects, based on well-performed monitoring of technology, market and customer needs. In Table 1, we describe how those elements (defined as variables at this point) impact on the three variety management axes presented on topic 2.3. It is important to emphasize that some variables impact only some axes.

Table 1. Portfolio management variables and their impact on variety management axes.

\begin{tabular}{|c|l|}
\hline $\begin{array}{c}\text { Selection of the portfolio } \\
\text { of new products }\end{array}$ & $\begin{array}{l}\text { Complexity: it reduces the ideas universe (marketing demands) to the enterprise's strategic capacity. } \\
\text { Integration: different organizational areas are necessary to perform portfolio meetings. }\end{array}$ \\
\hline $\begin{array}{c}\text { Portfolio Management of } \\
\text { ongoing projects }\end{array}$ & $\begin{array}{l}\text { Complexity: it controls the product strategic alignment (eliminates projects that will not achieve the strategic objectives). } \\
\text { Flexibility: it controls the product development process and guarantees that deliverables and schedule are achieved. } \\
\text { Integration: it involves different organization areas (Project stage-gates). }\end{array}$ \\
\hline Technological monitoring & $\begin{array}{l}\text { Complexity: it creates new product opportunities based on technologies. } \\
\text { Flexibility: it allows perceiving technological opportunities before competition. }\end{array}$ \\
\hline $\begin{array}{c}\text { Market monitoring (macro } \\
\text { economical) }\end{array}$ & $\begin{array}{l}\text { Complexity: it creates new product opportunities based on market. } \\
\text { Flexibility: it allows perceiving market opportunities before competition. }\end{array}$ \\
\hline $\begin{array}{c}\text { Market monitoring } \\
\text { (client's needs) }\end{array}$ & $\begin{array}{l}\text { Complexity: it eliminates product variants that are not aligned with the clients' needs. } \\
\text { Flexibility: it frees up time for the development of product variants aligned to market needs. } \\
\text { Integration: it links market vision to the engineering, avoiding rework. }\end{array}$ \\
\hline
\end{tabular}




\subsection{Standardization and modularization}

According to Pahl et al. (2007), standardization is employed, among other usages, to increase the amount of repetitive parts through their use in different products. For them, it is possible to achieve parts' standardization via similarity analysis. For Jiao et al. (2007), the use of standardized parts reduces variety but avoids increasing production costs, while allowing the offer of different products.

For Fujita et al. (1999), modularity is another way to obtain standardization. On the other hand, for Mohamad et al. (2013), standardization can be seen as part of the modularization process and can be applied to a module's parts, interfaces and to the module itself. To Pahl et al. (2007), modular products are systems, subsystems or parts that allow to perform distinct overall functions through different building blocks or modules. They differ from simple assemblies due to their standardized interfaces and maximum interchangeability. To Baldwin and Clark (2000), modularity is an approach to building complex processes or products from smaller subsystems that can be individually developed, but work as an integral set.

Works dealing with the benefits of using modularity and standardization are found in the literature. Lau (2011) revealed three benefits directly related to variety management: economy of scale, due to higher production of modules; higher creation of variety without the need of proportional creation of parts; and the enabling of mass customization. Fujita et al. (1999) share the opinion that the benefits of modularization fall into economy of scale. Kaczmarek et al. (2016) have employed modularity as a mean to develop wind turbine rotor blades that are suitable to be produced in series, reducing product variety and design effort.

Lau (2011) also pointed out postponement as another modularization benefit. Postponement allows for the production of basic modules based on forecast demand (make-to-stock), while variant modules manufacturing and assembly can be performed after the client's order (make-to-order and assembly-to-order), reducing the production response time and increasing flexibility. To Graziadio (2004), delaying the manufacture of modules allows the enterprise to produce products more aligned to the customer needs. To Sako and Murray (1999), the logic of using modularity on production is related to Fordism principles of standardization and task unification.

We present the evaluation of the observed variables against the variety management axes in Table 2 . It is important to notice that both modularity and standardization lead to a differentiation in latter manufacturing phases, during assembly, reducing the total number of SKUs and increasing produced units and providing gains of economy of scale.

\subsection{Concurrent engineering}

According to Prasad (1996), Concurrent Engineering (CE) is based on two wheels. The first one is the organized integration of products and processes. The second is the integrated product development. It results in an environment with team work and cooperation based on a philosophy focused on product development, which, in turn, results in cost reduction, quality improvement and shortened time-to-market.

It is interesting to notice that $\mathrm{CE}$ can be improved with modularity principles. To Lau (2011), modularity increases the possibility of decoupling design activities and, consequently, making $\mathrm{CE}$ viable.

A CE based NPD indirectly aids variety management, since it allows reducing time-to-market and frees up design teams earlier for new projects. Furthermore, it allows for the early identification of problems that otherwise would only appear in latter phases of the project, thus, anticipating stage-gate decisions.

Table 3 summarizes the analysis of the observed variables against the variety management axes.

Table 2. Modularity and standardization variables and their impact on variety management axes.

\begin{tabular}{|c|l|}
\hline \multicolumn{1}{|c|}{ Variable } & \multicolumn{1}{c|}{ Impact on variety Management Axis } \\
\hline Modularity & $\begin{array}{l}\text { Complexity: it reduces the complexity by reducing the number of assemblies (modules) in new projects (platform). } \\
\text { Flexibility: reusing assemblies (modules) avoids the need to design a similar one in another project, reducing time-to-market. }\end{array}$ \\
\hline Standardization & $\begin{array}{l}\text { Complexity: it reduces parts variety creating internal item commodities. } \\
\text { Flexibility: it allows working with parts and processes already available, reducing the effort (and time) needed to } \\
\text { select parts. } \\
\text { Integration: to communalize parts, it is necessary to discuss both their design and manufacturing. So, it could be } \\
\text { seen as an enabler of the concurrent engineering. }\end{array}$ \\
\hline
\end{tabular}

Table 3. Concurrent Engineering variables and their impact on variety management axes.

\begin{tabular}{|c|l|}
\hline Variable & \multicolumn{1}{|c|}{ Impact on variety Management Axes } \\
\hline Concurrent Engineering & $\begin{array}{l}\text { Flexibility: it reduces time-to-market by using parallel activities. } \\
\text { Integration: it motivates interaction among people and roles. }\end{array}$ \\
\hline
\end{tabular}




\section{Variety management cases}

We performed two case studies in two different companies, chosen for their portfolio variety and established management methods, global presence and information availability. To elaborate them, we had technical visits and meetings with the management personnel directly related to the variety management on the Product Development Process (PDP). The names and distinctive characteristics of each enterprise will not be disclosed on the companies' request. Our case study analysis is provided at the end of this topic, and the gathered parameters are presented.

\subsection{Company A}

Company A is a global company that produces user goods under different brands, with several units around the world. Its hierarchy is well structured, and the regional head office centralizes portfolio decision making, and controls marketing, sales and logistics overall planning. In the company's organizational structure, the product development administration and marketing departments are directly under the CEO. Attached to the CEO's office is the Strategic Planning Area, responsible for macroeconomic prospection (i.e., global opportunities and trade barriers). All strategic planning is focused on sales.

Marketing administration is responsible for market intelligence, gathering information on market trends and their manifestations. The Product Development administration is responsible for technological monitoring, looking for possible disruptive innovations, and keeping an eye on the competition. All available information (market intelligence, macroeconomic scenarios and technological prospection) is employed to stablish the product portfolio, based on the company's strategic planning.

A project office linked to the product development administration converts the product portfolio into projects using a software to follow project management. Projects are divided into categories based on their complexity: larger projects use all information provided by the Product Development Process (PDP) reference model and smaller projects use an adapted reference model, derived from the full version, but customized to the problem. For the company, managing smaller and larger projects together is important, especially when bottleneck resources are involved. This company manages more than 70 projects simultaneously, spread into several product engineering units.

Projects are carried out by project teams located on the different industrial areas in the cities. Each product engineering department is specialized in a product category related to the industrial area to which it is allocated. To aid the variety management, the company employs modularity and standardization techniques. Project management is supported by a software that is integrated with the portfolio management software.

Product development occurs in a concurrent engineering environment, but the production takes control when product engineering releases the product's Bill of Materials (BOM) in the company's Enterprise Resource Planning (ERP) software, during the beginning of the launch phase. It also involves the planning of the phasing-out of old products and the phase-in of new products. The sales department is informed only at this stage, avoiding unnecessary expectations.

At this point, new products are integrated into the industrial production planning. That takes place in two levels, one related to long-term planning ( 3 months, last 2 weeks are frozen), another to short-term planning. Both levels are linked to marketing and sales administration at the headquarters. In this particular unit, the company deals with more than 5000 stock keeping units (SKU).

When asked to highlight main success factors for managing variety of products, the interviewee pointed out three main factors:

- Use of information systems

- Strategic prioritization

- Clear roles during decision making

For the interviewee, portfolio is the entrance for the growing variety, since it is directly related to $R \& D$, competition and market trends.

\subsection{Company B}

Company $\mathrm{B}$ is a national company with global operations that manufactures machines for other industries (market 1) and parts for the automotive industry (market 2). Considering its size, revenue and number of employees, it can be considered a large company. The whole industrial park is in one single area, but divided by markets, each treated individually. We visited and interviewed personnel in charge for market 1.

The company's sales for this particular market are controlled by the sales department, which is also responsible for marketing (products and brand disclosure only). The company does not create a sales forecasting, instead it provides a portfolio that is delivered to the sales network. To propose the portfolio of new products, the sales department focuses on price and profit. For this company, a new product must (or should) replace an existing one. However, the sales department is frequently sensitive with the removal of older products from the market.

It is important to notice that a product proposition is considered a new product by the product engineering department only when an investment order is open with 
necessity of more than 3000 development hours, when it represents a new market or is not in the product portfolio, and the monetary investment is above a reference level. On the other hand, for the production, a product is always considered new when it needs a new code.

A distinguishing factor observed in this company is the high informality in the interpersonal and interdepartmental relationships. It differs significantly from the previous company, centered on records and very clearly defined responsibilities. To support such informal process, regular meetings are established in daily and monthly basis, involving all departments' managers and key representatives. The daily meetings are initially managed by the Production planning and control department, with support from product development, sales and other departments. It is later carried out by Customer Care Services, focusing on gathered problems. The monthly meetings focus on innovation, market growth, financial results, quality and productivity.

This level of informality is only possible due to a continuously integrative posture from the management side. It is facilitated by the relative small number of employees in this industrial unity when compared to the previous company. However, it brings some occasional problems such as reminiscent stock when introducing new products.

This company was also observed to organize its design teams by sales channels. That arrangement allows for a more informal portfolio management due to a higher integration between sales personnel and more focus during the monthly meetings.

When asked to highlight main success factors for managing variety of products, the interviewee pointed out three main factors:

- Flexibility (to reduce product mix)

- Integration (to achieve some level of customization)

- Market ramification (to maintain high capillarity)

The company also pointed out some challenges, including cost reduction and agility improvement. It was also observed that the company is trying to introduce modularity in their products, and that the first modular family was just 2 years old.

\subsection{Cases assessment}

From both visits, we observed a direct correlation between complexity and variety amplitude (number of products). In our understanding, variety is the set of products demanded from the enterprise, including the current product portfolio and new concepts under development derived from market needs or new technologies. Higher demand levels lead to higher levels of information requirements.
Consequently, variety management will be more complex during product development.

On the other hand, organizational flexibility plays an important role in variety management. More flexible companies will be faster in delivering products to the market. It is also related to integration. More integrated companies, via software, such as Company A, or informality, such as Company B, provide faster information flow, positively impacting response time and, therefore, flexibility.

To better understand this context, we defined three axes:

- Variety, as the quantity of products and their variations demanded from the company's portfolio. It is directly related to variety management complexity due to technological or market opportunities, existing portfolio orders and, perhaps, unique projects to special clients. All those elements are pressure mechanisms to create more variety and are represented by arrows on Figure 1. The company has several layers of tools to deal with such demands. The first one is constituted from strategic resources to support decision making, such as technological and market forecasting, demand management and portfolio management. A second layer is provided on an engineering level, where tools such as modularity, standardization and demand forecast deliver less complex systems to production. The third layer is related to how production deals with the complexity and is out of this paper's scope.

- Flexibility, as the response time to customer expectations. This can have different meanings depending on the lifecycle stage the product is (for example, time-to-market to product development or lead-time to production).

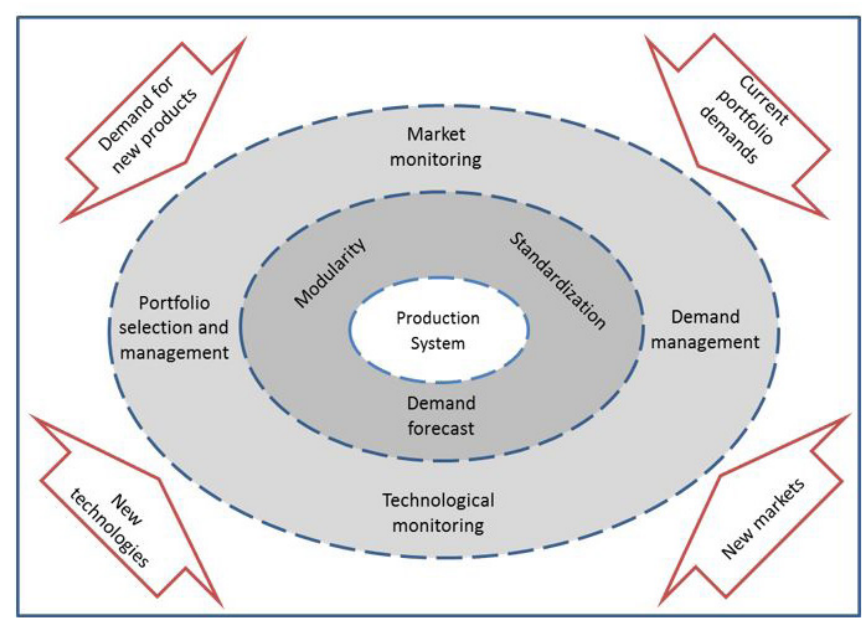

Figure 1. Variety management response mechanisms to deal with complexity created by variety demand. 
- Integration, as the grouping of parts that work separately. It can also be seen as the horizontalization of the information flow between departments, knowledge areas and roles. It is quite intuitive that more integrated teams work more efficiently and, unquestionably, faster than those otherwise.

To better understand integration, we created the diagram presented in Figure 2. It illustrates a generic company combining the information flow among different roles from both studied cases. The company's strategic plan provides guidance for all company's decisions. Marketing is responsible for understanding the client needs, to provide the insights to define the portfolio of new products, and to define products' phase-out based on sales history. Some level of technological and market forecasting is also necessary at this stage. Both companies use modularity and some level of standardization to reduce complexity (number of parts) and concurrent engineering principles to provide better integration.

As previously stated, complexity is directly related to the number of variants demanded for the portfolio (variety). To Lanza et al. (2010), the increase in variety causes different cost effects in different company divisions. To the author, those effects must be identified and compared to potential profits.

The relationship between complexity and integration is not a new observation in the literature. Garrett et al. (2006) stated that the integration between R\&D and Marketing for new product development (NPD) is an important element to improve its performance. Zhao et al. (2014) pointed out the importance of the integration with suppliers (black box parts) during NPD. However, Fliess and Becker (2006) stated that keeping control of integration processes with suppliers during NDP is necessary.
Millson and Wilemon (2002) investigated three hypotheses related to the success of a new product in the market. One of them is particularly interesting: a higher organizational integration during NPD is related to a higher proficiency of the NPD; and a higher NPD proficiency yields a stronger market success.

Considering the relationship between complexity and flexibility, Verganti (1999) stated that it is possible to build flexibility into the NPD process through early decisionmaking.

When dealing with integration, we consider that it has as basic principle of combining different parts that are working separately. In practice, it results in a more horizontal information flow by putting knowledge areas or physical sectors closer. Homburg and Kuehnl (2014) divided integration in external and internal. In this paper we are concerning internal integration, but external integration also plays an important role.

Some authors (FAGERSTRÖM; JACKSON, 2002; KOUFTEROS; EDWIN CHENG; LAI, 2007; PETERSEN; HANDFIELD; RAGATZ, 2005) emphasized the importance of the integration with suppliers during the NPD, with great benefits for the company's strategy and material cycles. On the other side of the integration, Nishikawa et al. (2013) studied the benefits of integrating customer ideas into the NPD and pointed out the possibility that products developed with customer participation often overcame products generated only by designers driven by key marketing requirements. To Füller et al. (2010), customer integration can be achieved via the Internet.

When focusing on flexibility and integration, Sánchez and Pérez (2003) showed that cooperative activities allow enterprises to develop new products faster than

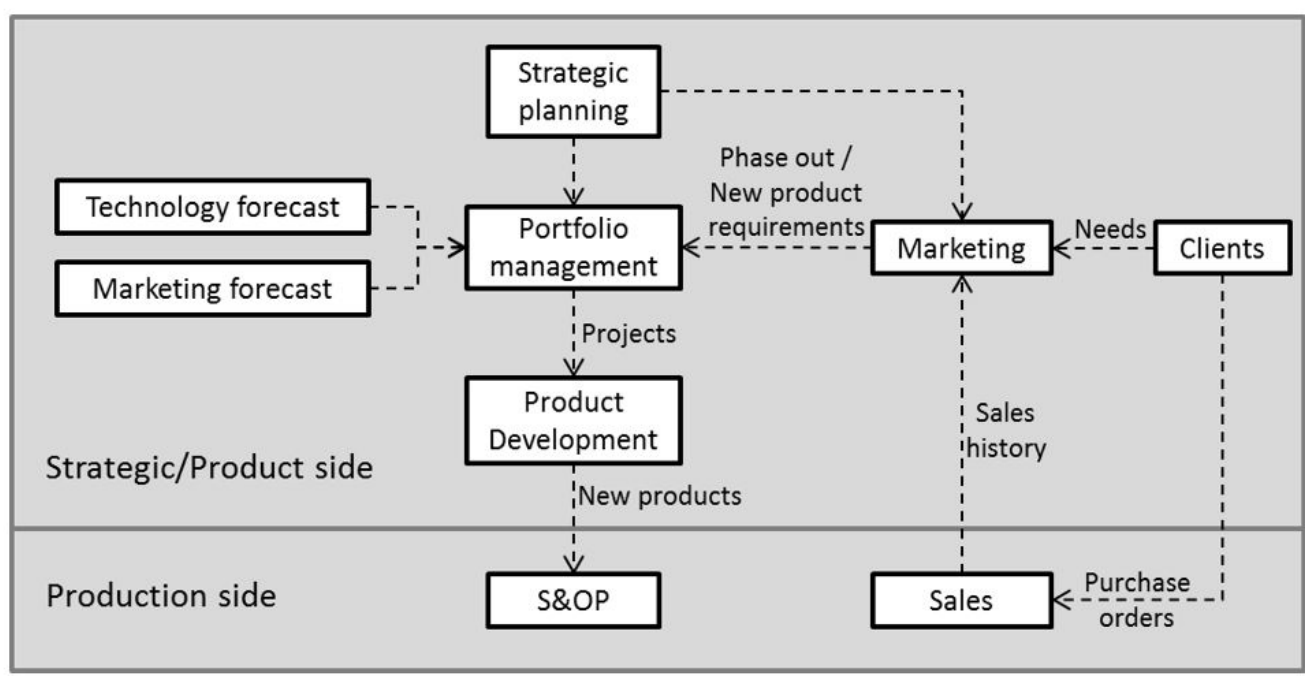

Figure 2. Combined information flow on studied organizations. 
their competition. Kahn (1996), from the interview with the R\&D department managers working for electronics, manufacturing and marketing industries, observed that collaboration and interaction between departments positively influence both the performance of the product development process and the performance of product management. The author emphasizes that collaboration will have a stronger effect than simple interaction.

As observed in the work of Chinnathai et al. (2017), the variety management performed during development greatly impacts the management of variety during production. As can be seen in Figure 2, it introduces complexity to the production side directly on the Company's Sales and Operation Planning (S\&OP). That side of the variety management is not addressed on this paper.

\section{Proposal of maturity levels}

After the study of the variables that affect the variety management axes, we proposed maturity levels for those variables (Table 4). Maturity is specified in three levels: basic (1), managed (3) and Continuous Improvement (5), with the possibility of two intermediate levels (2 and 4). So, during maturity level evaluation, it is possible to tell when an enterprise has fulfilled a particular level, but is still in course for the fulfillment of the next. The maturity levels must be evaluated according to each Variety variable observed during the previous topics. Every single Maturity Level for individual Variety Variables was established based on the literature for the proposed levels (Basic, Managed and Continuous Improvement) and on what was observed on our Variety Management Cases, on Topic 2.

Table 4. Variety management maturity levels.

\begin{tabular}{|c|c|c|c|}
\hline \multirow[b]{2}{*}{ Variables } & \multicolumn{3}{|c|}{ Maturity Levels } \\
\hline & $\begin{array}{c}(1) \\
\text { Basic } \\
\end{array}$ & $\begin{array}{c}(3) \\
\text { Managed }\end{array}$ & $\begin{array}{c}\text { (5) } \\
\text { Continuous Improvement }\end{array}$ \\
\hline $\begin{array}{l}\text { Selection of the portfolio of } \\
\text { new products }\end{array}$ & $\begin{array}{l}\text { Intuitively performed; informal; } \\
\text { without defined criteria; basic } \\
\text { strategic alignment. }\end{array}$ & $\begin{array}{l}\text { Use of pre-defined criteria; } \\
\text { integrated with different areas; } \\
\text { concerned with resources } \\
\text { allocation. Economic viability } \\
\text { monitored. }\end{array}$ & $\begin{array}{l}\text { Use of well-known portfolio } \\
\text { management techniques. All } \\
\text { enterprise areas are integrated. }\end{array}$ \\
\hline $\begin{array}{l}\text { Portfolio Management of } \\
\text { ongoing projects }\end{array}$ & $\begin{array}{l}\text { Ongoing projects are evaluated } \\
\text { informally or/and intuitively. }\end{array}$ & $\begin{array}{l}\text { Ongoing projects are evaluated } \\
\text { with pre-defined criteria. Risks, } \\
\text { technological and economic } \\
\text { viability are considered. }\end{array}$ & $\begin{array}{l}\text { Ongoing projects are evaluated } \\
\text { in formal gates. Product } \\
\text { Development Process may be } \\
\text { upgraded to perform corrections. }\end{array}$ \\
\hline Technological monitoring & $\begin{array}{l}\text { State-of-practice based } \\
\text { monitoring (visit to trade fairs, } \\
\text { informal benchmarks against } \\
\text { rival firms). Reactive. } \\
\end{array}$ & $\begin{array}{l}\text { Portfolio management is } \\
\text { integrated with technological } \\
\text { monitoring to define } \\
\text { technological viability. }\end{array}$ & $\begin{array}{l}\text { Proactive organization that } \\
\text { creates its own technology } \\
\text { based on technological trends. } \\
\text { Integrated with R\&D. }\end{array}$ \\
\hline $\begin{array}{l}\text { Market monitoring } \\
\text { (macro-economic) }\end{array}$ & $\begin{array}{l}\text { Simple market surveys or } \\
\text { acquisition of market reports for } \\
\text { the sector. More reactive. }\end{array}$ & $\begin{array}{l}\text { Formal studies of market } \\
\text { opportunities. Proactive. }\end{array}$ & $\begin{array}{l}\text { Continuous monitoring for } \\
\text { potential market opportunities. } \\
\text { Integrated with portfolio } \\
\text { management. }\end{array}$ \\
\hline $\begin{array}{c}\text { Market monitoring (client's } \\
\text { needs) }\end{array}$ & $\begin{array}{l}\text { Client's needs are obtained } \\
\text { internally. Requirements are } \\
\text { obtained without formal tools. }\end{array}$ & $\begin{array}{l}\text { Client's needs are obtained } \\
\text { externally. Use of formal tools } \\
\text { (i.e., QFD, Life Cycle Analysis) } \\
\text { to define product requirements. }\end{array}$ & $\begin{array}{l}\text { Continuously monitoring of } \\
\text { clients' needs and product } \\
\text { requirements. Lessons learned } \\
\text { are employed on new projects. }\end{array}$ \\
\hline Modularity & $\begin{array}{l}\text { There are no modules or } \\
\text { modules are defined intuitively. }\end{array}$ & $\begin{array}{l}\text { All product platforms are } \\
\text { formally designed based on } \\
\text { modularity methodological } \\
\text { process. }\end{array}$ & $\begin{array}{l}\text { Modular product platforms are } \\
\text { well-managed and integrated } \\
\text { with Portfolio management. } \\
\text { Inter-platform modules are also } \\
\text { considered. }\end{array}$ \\
\hline Standardization & $\begin{array}{l}\text { Basic and intuitive } \\
\text { standardization (i.e. fastenings). }\end{array}$ & $\begin{array}{l}\text { Formalized standardization, } \\
\text { with the approval of product } \\
\text { development and manufacturing. } \\
\text { Mainly commodities. }\end{array}$ & $\begin{array}{l}\text { Standardization also includes } \\
\text { internally designed parts. Formal } \\
\text { requirements are necessary to } \\
\text { change standardized parts. }\end{array}$ \\
\hline Concurrent Engineering & $\begin{array}{l}\text { There aren't concurrent } \\
\text { engineering activities or } \\
\text { initiatives are very informal. }\end{array}$ & $\begin{array}{l}\text { Product development, Marketing } \\
\text { and Production activities usually } \\
\text { share common and concurrent } \\
\text { activities, using tools to facilitate } \\
\text { the work (i.e. QFD and FMEA). }\end{array}$ & $\begin{array}{l}\text { Fully integration between } \\
\text { departments. Uses software to } \\
\text { support CE. }\end{array}$ \\
\hline
\end{tabular}


It is important to notice that each maturity represents complete degrees of practices performed by a particular organization for the corresponding variety variable. For example, if a company is trying to provide a more formalized process for part standardization and already has standardized fasteners, it has basic stage fulfilled, but is still not ranked as "managed", so it is ranked as level 2.

This Tool was designed to support companies to evaluate their Variety Management skills and to help them drive their efforts to enhance their performance. The tool evaluation is presented in the next topic.

\section{Tool evaluation}

To evaluate the proposed tool, it was presented to three companies with the following profiles:

- Companies A and B are multinational companies that produce different types of machining tools.

- Company C produces metal parts for the automotive and agricultural sectors, and industrial electro-technical components. This company is national, but with international operations.

Each company received a short presentation about this project, a short description of how to use the proposed tool and a checklist based on Table 4, to which columns

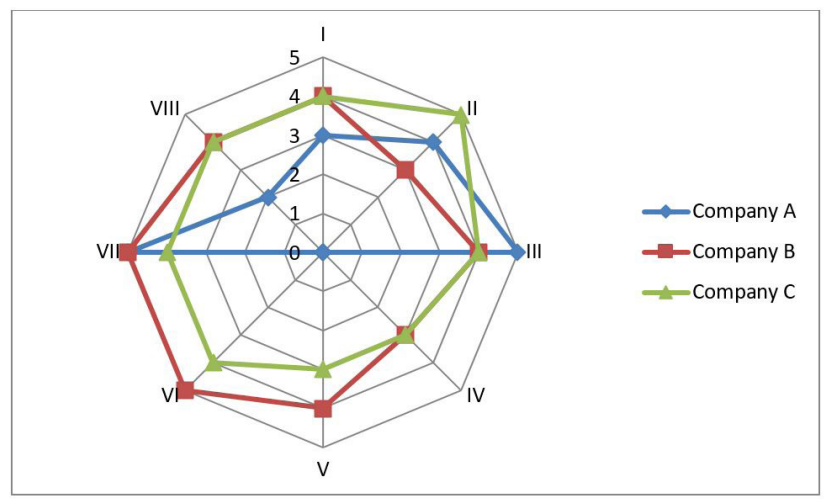

Figure 3. Radar chart for gathered data. representing the intermediate maturity levels 2 and 4 were added. The results are presented in Table 5

At this point, it is clear that the proposed variables can be easily employed for the evaluation of variety maturity levels. Some improvements can be made to the questionnaire to include level zero of maturity for cases such as Company A, which doesn't need or use some variables.

Besides, the tool also demonstrates an unexpected yet useful ability to be employed as a benchmarking tool. Figure 3 shows a radar chart for the data provided in Table 5. In the case of rival companies, Company B should address the variety variable "Portfolio Management of ongoing projects" (axis II) to achieve performance levels similar to Company $\mathrm{C}$, for example.

\section{Final remarks}

The main scope of this research was to identify and organize the variables related to the variety management on industrial enterprises. The variety management in the Product Development Process (PDP) was verified to mainly consist of handling the high variety of products existing in the portfolio, triggered by an increasingly demanding consumer market.

Successful enterprises use project portfolio management techniques to significantly and crucially help manage multiple project environments and a wide variety of products on the production line, providing strategic and tactical guidance for project management. Another factor of great relevance is the selection of the portfolio of new products. Correct selection, coupled with the monitoring of technologies and markets, leads to a reduction in the complexity caused by the large number of new product ideas, and helps meeting the expectations of the market. It is an important variable in the variety management since, besides involving different areas, it is the factor that determines the level of product variety in the portfolio.

Within the PDP itself, the adoption of concurrent engineering techniques, modularization and standardization are observed to be able to reduce the complexity generated by the high variety of products, decrease the response

Table 5. Maturity level assessment for 3 companies.

\begin{tabular}{|c|l|c|c|c|}
\hline \multicolumn{2}{|c|}{ Questions/variables } & Company & Company & Company \\
B & \multicolumn{2}{c|}{ C } & 4 & 4 \\
\hline I & Selection of the portfolio of new products & 3 & 3 & 5 \\
\hline II & Portfolio Management of ongoing projects & 4 & 4 & 4 \\
\hline III & Technological monitoring & 5 & 3 & 3 \\
\hline IV & Market monitoring (macro-economic) & N.I.* & 4 & 3 \\
\hline V & Market monitoring (client's needs) & N.I.* & 5 & 4 \\
\hline VI & Modularity & N.I.* & 5 & 4 \\
\hline VII & Standardization & 5 & 5 & 4 \\
\hline VIII & Concurrent Engineering & 2 & 4 \\
\hline
\end{tabular}

\footnotetext{
* Not Informed.
} 
time after the opportunity identification and facilitate the integration in the project. This way, it enables companies to develop better products in a more efficient, faster and less complex fashion.

Based on the observed variables, a questionnaire was proposed to evaluate the maturity levels of the industrial enterprises. The results obtained from the questionnaire can be compared between companies to perform a variety maturity benchmark. In future works, it is possible to perform a broader information gathering to evaluate the possibility of adopting the same maturity levels in other industrial environments.

\section{Acknowledgements}

We are grateful to the other participants of the Variety Management project for their insights and contributions to this part of the project. We also thank CNPq and UDESC for the scientific initiation grants provided to support this project.

\section{References}

ARCHER, N. P.; GHASEMZADEH, F. An integrated framework for project portfolio selection. International Journal of Project Management, v. 17, n. 4, p. 207-216, 1999.

BALDWIN, C. Y.; CLARK, K. B. Design rules: the power of modularity. USA: MIT Press, 2000. $1 \mathrm{v}$.

CHINNATHAI, M. K.; ALKAN, B.; HARRISON, R. Convertibility evaluation of automated assembly system designs for high variety production. Procedia CIRP, v. 60, p. 74-79, 2017. http://dx.doi.org/10.1016/j.procir.2017.01.005.

CLARK, K. B.; WHEELRIGHT, S. C. Managing new products and process development: text and cases. New York: Free Press, 1993. 896 p.

COOPER, R. G. Winning at new products: accelerating the process from idea to launch. 2nd ed. Nova York: Basic Books, 2001. p. 358.

COOPER, R. G.; EDGETT, S. J.; KLEINSCHIMIDT, E. J. Portfolio management for new products. Massachusetts: Addison-Wesley, 1998.

ELMARAGHY, H. et al. Managing variations in products, processes and manufacturing systems. CIRP Annals Manufacturing Technology v. 58, n. 1, p. 441-446, 2009. Available from: <http://www.sciencedirect.com/science/ article/pii/S0007850609001267>. Access in: 10 May 2017.

FAGERSTRÖM, B.; JACKSON, M. Efficient collaboration between main and sub-suppliers. Computers in Industry, v. 49, n. 1, p. 25-35, 2002.
FLIESS, S.; BECKER, U. Supplier integration: controlling of co-development processes. Industrial Marketing Management, v. 35, n. 1, p. 28-44, 2006.

FUJITA, K.; SAKAGUCHI, H.; AKAGI, S. Product variety deployment and its optimization under modular architecture and module commonalization. In: ASME DESIGN ENGINEERING TECHNICAL CONFERENCE, 1999, Las Vegas. Proceedings... New York: ASME; 1999. p. 1-12.

FÜLLER, J.; FAULLANT, R.; MATZLER, K. Triggers for virtual customer integration in the development of medical equipment - From a manufacturer and a user's perspective. Industrial Marketing Management, v. 39, n. 8, p. 1376-1383, 2010. http://dx.doi.org/10.1016/j. indmarman.2010.04.003.

GARRETT, T. C.; BUISSON, D. H.; YAP, C. M. National culture and $\mathrm{R} \& \mathrm{D}$ and marketing integration mechanisms in new product development: a cross-cultural study between Singapore and New Zealand. Industrial Marketing Management, v. 35, n. 3, p. 293-307, 2006.

GRAZIADIO, T. Estudos comparativos entre fornecedores de computadores automotivos de placas convencionais e modulares. 2004. 175 f.Tese (Doutorado em Engenharia de Produção)-Escola Politécnica, Universidade de São Paulo, São Paulo, 2004.

HALL, D. L.; NAUDA, A. An interactive approach for selecting IR\&D projects. IEEE Transactions on Engineering Management, v. 37, n. 2, p. 126-133, 1990.

HOMBURG, C.; KUEHNL, C. Is the more always better? A comparative study of internal and external integration practices in new product and new service development. Journal of Business Research, v. 67, n. 7, p. 1360-1367, 2014. http://dx.doi.org/10.1016/j.jbusres.2013.08.017.

JIAO, J.; ZHANG, L.; POKHAREL, S. Process platform planning for variety coordination from design to production in mass customization manufacturing. IEEE Transactions on Engineering Management, v. 54, n. 1, p. 112-129, 2007.

JONAS, D.; KOCK, A.; GEMUENDEN, H. G. Predicting project portfolio success by measuring management quality: a longitudinal study. IEEE Transactions on Engineering Management, v. 60, n. 2, p. 215-226, 2013.

KACZMAREK, S. et al. Improving design efforts and assembly efficiency of rotor blade carriers through modularisation. Procedia CIRP, v. 50, p. 76-81, 2016. Available from: <http://linkinghub.elsevier.com/retrieve/ pii/S2212827116304747>. Access in: 10 May 2017.

KAHN, K. B. Interdepartmental integration: a definition with implications for product development performance. Journal of Product Innovation Management, v. 13, n. 2, p. 137-151, 1996. 
KOUfteros, X. A.; EDWIN CHENG, T. C.; LAI, K. H. "Black-box" and "gray-box" supplier integration in product development: antecedents, consequences and the moderating role of firm size. Journal of Operations Management, v. 25, n. 4, p. 847-870, 2007.

LANZA, G. et al. Assessment of flexible quantities and product variants in production. CIRP Journal of Manufacturing Science and Technology, v. 3, n. 4, p. 279-284, 2010.

LAU, A. K. W. Critical success factors in managing modular production design: six company case studies in Hong Kong, China, and Singapore. Journal of Engineering and Technology Management - JET-M, v. 28, n. 3, p. 168-183, 2011. http://dx.doi.org/10.1016/j.jengtecman.2011.03.004.

MESKENDAHL, S. The influence of business strategy on project portfolio management and its success: a conceptual framework. International Journal of Project Management, v. 28, n. 8, p. 807-817, 2010. Available from: $<$ http://modir3-3.ir/article-english/article309.pdf $>$. Access in: 31 May 2017.

MILLSON, M. R.; WILEMON, D. The impact of organizational integration and product development proficiency on market success. Industrial Marketing Management, v. 31, n. 1, p. 1-23, 2002.

MOHAMAD, A. et al. Use of modularization in design as a strategy to reduce component variety in one-off projects. Product Development and Design Management, p. 289298, 2013.

NISHIKAWA, H.; SCHREIER, M.; OGAWA, S. Usergenerated versus designer-generated products: a performance assessment at Muji. International Journal of Research in Marketing, v. 30, n. 2, p. 160-167, 2013. http://dx.doi. org/10.1016/j.ijresmar.2012.09.002.

$\mathrm{OH}$, J.; YANG, J.; LEE, S. Managing uncertainty to improve decision-making in NPD portfolio management with a fuzzy expert system. Expert Systems with Applications, v. 39, n. 10 , p. $9868-9885,2012$.

OLIVEIRA, M. G.; ROZENFELD, H. Integrating technology roadmapping and portfolio management at the front-end of new product development. Technological Forecasting and Social Change, v. 77, n. 8, p. 1339-1354, 2010.
PAHL, G.; WALLACE, K.; BLESSING, L. Engineering design: a systematic approach. USA: Springer, 2007. v. 157.

PETERSEN, K. J.; HANDFIELD, R. B.; RAGATZ, G. L. Supplier integration into new product development: coordinating product, process and supply chain design. Journal of Operations Management, v. 23, n. 3-4, p. 371-388, 2005.

PRASAD, B. Concurrent engineering fundamentals. USA: Prentice Hall Englewood Cliffs, NJ, 1996. v. 1.

RANDALL, T.; ULRICH, K. Product variety, supply chain structure, and firm performance: analysis of the U.S. bicycle industry. Management Science v. 47, n. 12, p. 1588-1604, dez. 2001. Available from: <http://pubsonline.informs. org/doi/abs/10.1287/mnsc.47.12.1588.10237>. Access in: 10 May 2017.

SAKO, M.; MURRAY, F. Modules in design, production and use: implications for the global auto industry. In: INTERNATIONAL MOTOR VEHICLE PROGRAM (IMVP) ANNUAL SPONSORS MEETING, 1999, Cambridge. Proceedings... Cambridge: Massachusetts Institute of Technology, 1999.

SÁNCHEZ, A. M.; PÉREZ, M. P. Flexibility in new product development: a survey of practices and its relationship with the product's technological complexity. Technovation, v. 23, n. 2, p. 139-145, 2003. Available from: <http:// linkinghub.elsevier.com/retrieve/pii/S0166497201000967>. Access in: 10 May 2017.

TSENG, H.-E.; CHANG, C.-C.; LI, J.-D. Modular design to support green life-cycle engineering. Expert Systems with Applications, v. 34, n. 4, p. 2524-2537, 2008. Available from: <http://www.sciencedirect.com/science/article/pii/ S0957417407001443>. Access in: 10 May 2017.

VERGANTI, R. Planned flexibility: linking antecipation and reaction in product development projects. Journal of Product Innovation Management, v. 16, n. 4, p. 363-376, 1999.

ZHAO, Y.; CAVUSGIL, E.; CAVUSGIL, S. T. An investigation of the black-box supplier integration in new product development. Journal of Business Research, v. 67, n. 6, p. 1058-1064, 2014. http://dx.doi.org/10.1016/j. jbusres.2013.06.006. 